\title{
ISABEL PRIESTLY'S BOTANICAL STUDIES FOR DUCKS UNLIMITED
}

C. STUART HOUSTON, 863 University Drive, Saskatoon, Saskatchewan. S7N 0J8

In the summers of 1943,1944 and 1945, Mrs. Priestly devoted much of her time to botanical studies for Ducks Unlimited. The first summer, her collections were confined to the Upper and Lower Rousay Lakes (see Figure 1) west of Yorkton. During the next two years she extended the area to include York Lake, south of town, and Leech Lake. Illinois hunters had contributed money designated for what was called the "Lake Illinois Project."
The full titles of the three reports were similar. That for 1944 was: "A SURVEY OF THE VEGETATION OF THE ROUSAY LAKES, YORK LAKE AND LEECH LAKE, YORKTON, SASKATCHEWAN made during the summer of 1944; with notes on its relationship to the faunal life of the area, to Ducks Unlimited, Winnipeg, Manitoba, by Isabel M. Priestly."

The timing was propitious. After more than a decade of drought, a

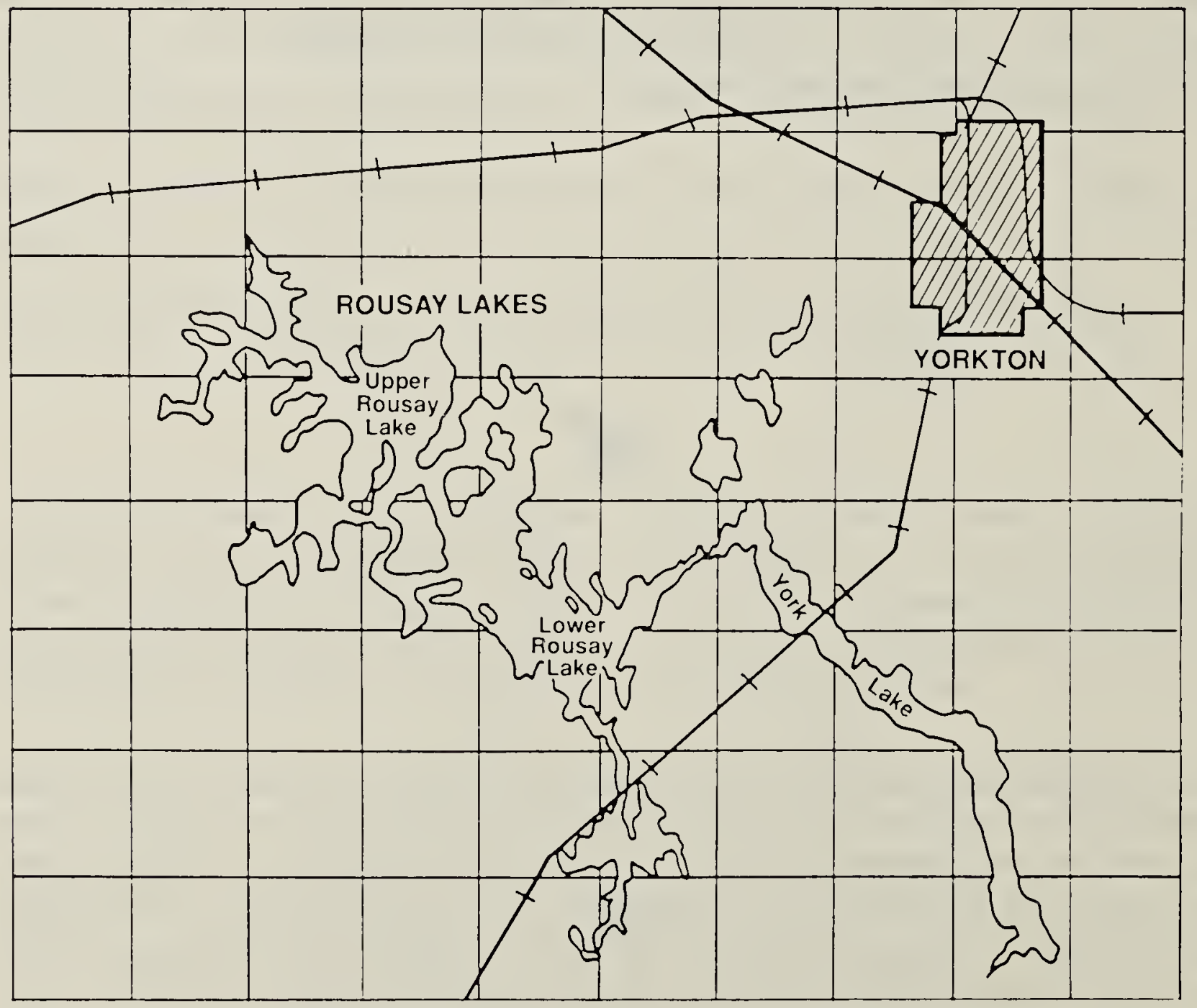

Figure 1. The Rousay and York Lakes were Isabel Priestly's study area, 1943-45. 
good snow was followed by spring rains in 1942, the first year that water was diverted from Willowbrook Creek by Ducks Unlimited. The Rousay Lakes had once before been completely dry, the year that Robert Rousay arrived in 1889; they did not fill until 1896. Leech Lake was dry at the same time and filled up two or so years later. About 1902, Dr. T.A. Patrick dug a ditch to allow some water to come down from Willowbrook Creek and stabilize the water levels. In the 1920s, at the peak of the water cycle, Upper Rousay Lake was ten feet deep and had a swimming beach. At the annual picnic from St. Magnus School, one man got beyond his depth and drowned. Lower Rousay Lake was so deep that Harvey Wood and his brothers, on a raft, were marooned when they could not touch bottom with a 10 -foot pole. In 1928, Dr. C.J. Houston was taken in a motorboat from York Lake through Lower Rousay Lake, up to the Robert Rousay farm at the top of Upper Rousay Lake. At York Lake, a bandstand and many cottages were built and an annual sailing regatta held.

With drought, water levels dropped by 1934 and most cottages at York Lake were deserted. The two Rousay Lakes became completely dry in 1937 and 1938, when Upper Rousay Lake was a large mud flat and hay was cut across Lower Rousay Lake. Just enough runoff came in 1940 and 1941 to prevent hay cutting in the lower lake bed. In 1942, Ducks Unlimited dug a ditch to divert water from Willowbrook Creek and the lakes were restored to life. In 1943 , with the help of a large spring runoff in the Beaver Hills, enough water was diverted to restore both the Rousay Lakes and York Lake, and a trickle of overflow went on down to Leech Lake.

In 1943, Mrs. Priestly collected a set of pressed specimens of 80 plants to accompany her report. She collected 90 specimens in 1944 and 70 in 1945 . Her carefully typed, single-spaced reports, totalled respectively 16,23 and 18 pages. If memory serves me correctly, she was paid $\$ 200$ each summer for the report and collections. George F. Ledingham, then teaching at the Junior College, Moose Jaw, identified the sedges; R.C. Russel, Dominion Laboratory of Plant Pathology, Saskatoon, certain grasses; T.J. Arnason, University of Saskatchewan, an aquatic moss; Alan A. Beetle, University of California, the buliushes.

When she was in the field collecting, Mrs. Priestly carried her vasculum, painted green, with a handle for easy carrying. She would open the lid, pop a moist plant inside, then close the lid. I couldn't believe how many plants the vasculum would hold, and how moist they stayed all day. When she got home she separated the plants, laid them on newspaper and pressed them in a plant press. Later they were carefully mounted on white cardboard sheets and labelled as to locality, date and species, for permanent storage. To me these sheets were works of art, truly objects of beauty. When Mrs. Priestly died, I received her precious vasculum as a keepsake; it became an essential item for my wife Mary's plant collecting before the days of plastic bags.

I was entranced by the names of the main duck foods, Myriophyllum spicatum, Water-milfoil, and the two common species of pondweed, Potamogeton pectinatus, Sago Pondweed and Potamogeton 
vaginatus, Sheathed Pondweed. Mrs. Priestly did her best, but these were among the few species of aquatic plants I learned to identify with absolute certainty. I impressed my friends and visiting naturalists by rolling their names off my tongue!

Of the 26 plants listed as duck food in western Canada, in Food of Game Ducks in the United States and Canada, published in 1939, Mrs. Priestly found that the three species listed above, plus Scirpus, bulrush; Carex, sedge; Eleocharis, spikerush; and Fluminea festucacea, Whitetop Grass, were abundant. Polygonum, smartweed or persicaria; Lemna, duckweed; Ranunculus, buttercup; Hippuris, mare's-tail; Symphoricarpos, snowberry; Galium, bedstraw; Rosa and Algae were common. Chara, muskgrass; Sparganium, bur-reed; and Sagittaria, arrowhead, were uncommon. That year there was only one occurrence of Typha, cattail.

Mrs. Priestly was interested in the interrelations between the plants and animals. In 1943 every pond and small slough was marked by one or more muskrat houses. Muskrat houses on Upper Rousay Lake were counted on 11 November by skating on the ice around the shorelines. There were 194 houses. This number increased to 576 in 1944, 1,200 in 1945 and 1,660 in 1946 in spite of a controlled trapping by 33 trappers who in ten days took 2,614 pelts in late March 1946. The pelts averaged $\$ 2.62$ per pelt, and yielded more money per acre than any adjacent acre of farm land yielded from wheat. [See W.A. Brownlee, "Muskrats," The Blue Jay 5:19, 1947.]

Mrs. Priestly's 1943 report included notes on the hawks, crows ("not excessively abundant") and the
Black-billed Magpie, with the exciting news that a family of this new invader from the southwest had been noted near York Lake. However, no magpies were seen in 1944.

In 1944, the cattail was becoming re-established along all four lakes studied, a striking change from the previous year. Phragmites, reed grass, was noted in several places on Upper Rousay Lake. Chara also showed a marked increase in abundance. She reported, "The bulrush, Scirpus, is undoubtedly the most important plant in the area from the standpoint of wildlife economy, providing as it does food, cover and nesting material for both bird and animal life. The dense stands of bulrush also shelter many lesser aquatic plants, and smaller aquatic insects and organisms."

Along the drainage channel into Upper Rousay Lake, the dominant sedge was Carex atherodes, Awned Sedge, followed by Carex lanuginosa, Woolly Sedge, and Carex aquatilis, Water Sedge.

In 1944, the fine duck marsh between Lower Rousay Lake and York Lake, an excellent duck breeding area in 1943, dried out and was grazed over by cattle. The channel between the lakes, choked with Water-milfoil, Crowfoot and Bladderwort early in the season, dried completely. Drepanocladus fluitans, Aquatic Moss, was present in heavy growth around the edge of the lakes, before the bulrushes started to grow up, in 1944. Water-milfoil grew profusely in the lakes; Mrs. Priestly reported that I had observed Lapland Longspurs landing on the stems of the milfoil and feeding on the seeds in three-feet deep water in the duckhunting season. 


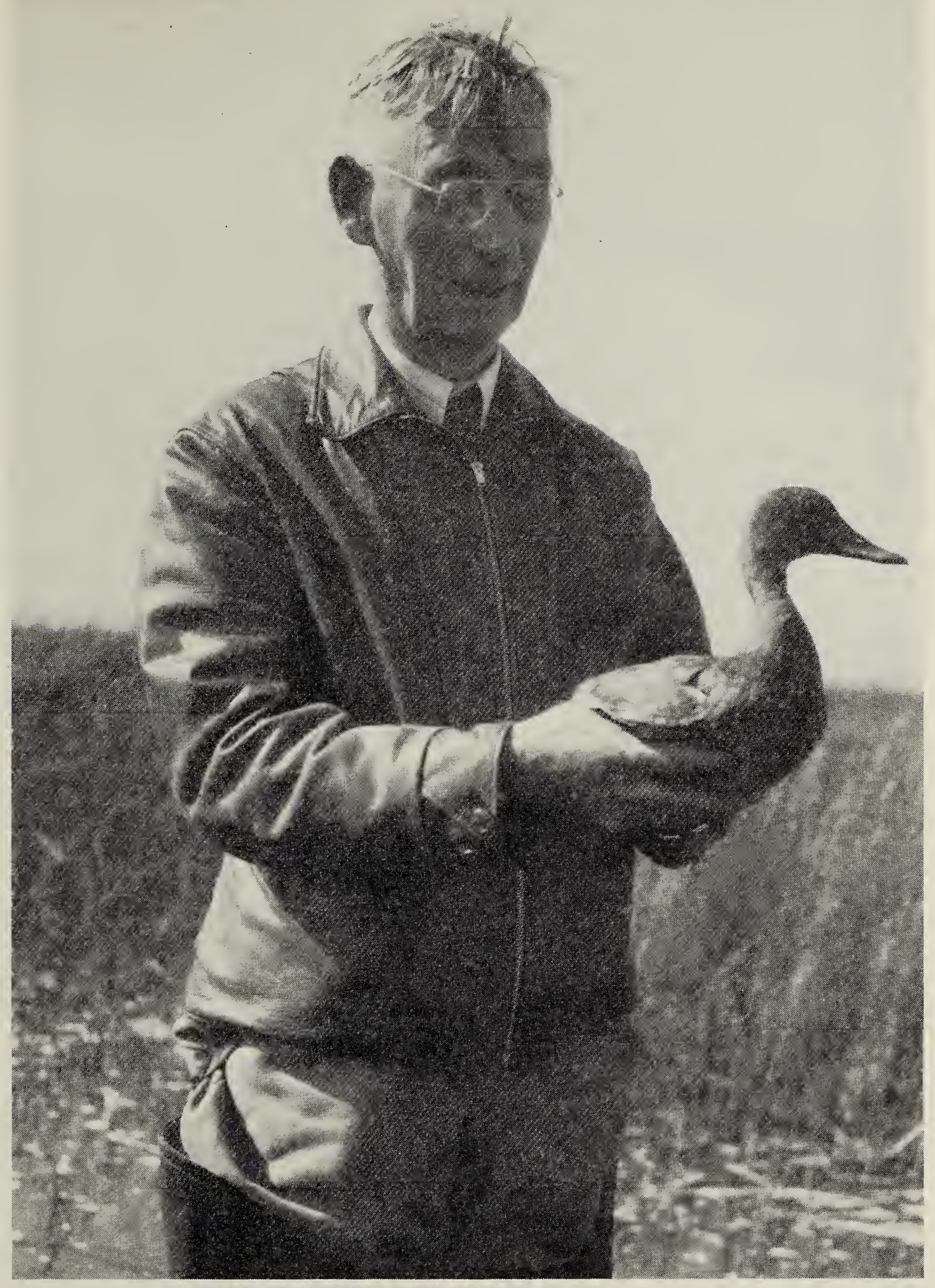

J.R. Foreman holding Mallard, 1943, Upper Rousay Lake

James D. Smith

Ricciocarpus natans, Purple- listed only for eastern Manitoba. fringed Riccia, floated on the surface Carex athrostachya, Long-bracted of a small bay at Upper Rousay Sedge, was the farthest east record Lake. Mrs. Priestly also collected for the province. Teucrium occidenRiccia fluitans, Slender Riccia, a talis, Western Wood Sedge or Hairy range extension of this species then Germander, common in pastures 


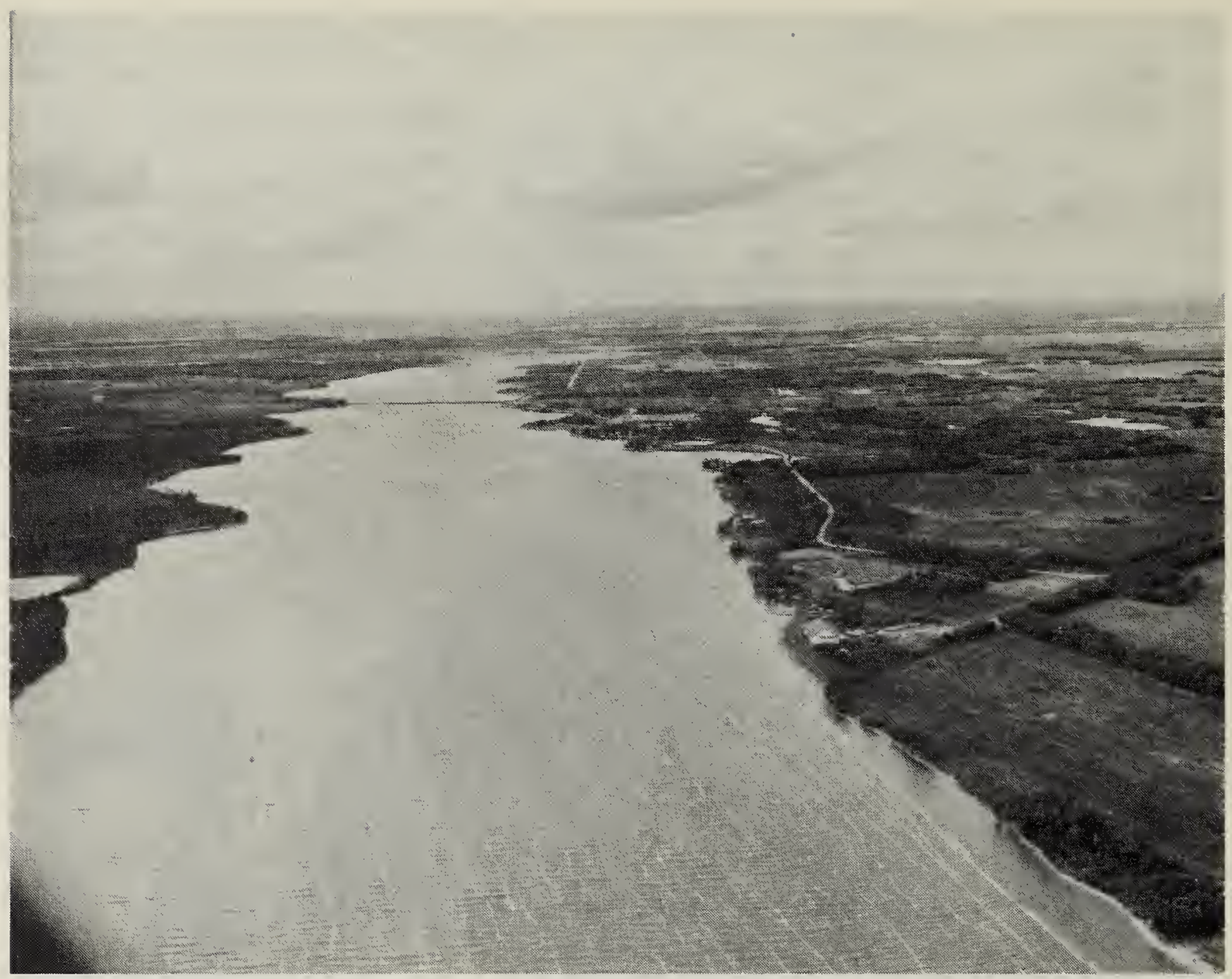

York Lake from the air.

around the lakes, was an addition to the Saskatchewan Plant List.

Extending her study to Leech Lake for the first time, she found that Scirpus paludosus, the Prairie or Alkali Bulrush, was the dominant plant there, with a thick carpet of it skirting the shore. As water receded, a special association of Suaeda, Sea-blite; Rumex, Dock; Aster brachyactis, Rayless Aster; and two species of Goosefoot sprang up.

In 1945 a modest spring runoff, coupled with timely rains in May and June, was sufficient to maintain water levels throughout the summer. In low-lying pastures around Upper Rousay Lake, severe overgrazing caused thistles and wild barley to replace the native grasses. An unfortunate grass fire, believed set by a farmer on the south side of the lake on 24 May, caused great wildlife mortality. A short walk on 10 June found six duck nests and two meadowlark nests with burned eggs. Later in the season wild barley covered the entire burn area. On the east side of Upper Rousay Lake, cattle ate the bulrush shoots as they appeared, forming a nearly bare shoreline that became the favourite loafing place for hundreds of ducks later in the summer.

Glyceria, Manna Grass, was luxuriant in every small pond. Mrs. Priestly postulated that the heavy growth of this grass meant a great decrease in mortality among young ducklings who in 1945 stayed on the smaller ponds until well grown, whereas in 1944 they were forced to seek the lakes soon after hatching. A heavy growth of Water Crowfoot also occurred in many ponds.

A new species collected in 1945 
was Alisma Geyeri, Geyer's or Narrow-leaved Water-plantain. The young leaves of this plant were consumed by ducks.

In 1945, crows became more of a menace and destroyed all the eggs of a new colony of nesting American Avocets at Leech Lake. Local hunters claimed that the American Coot was driving the Canvasback from Rokeby Marsh, so Mrs. Priestly compared the aquatic vegetation of the two marshes and examined the stomach contents of coots killed by hunters at Rokeby Marsh. She found the coots were eating muskgrass, whereas the Canvasbacks ate Sago Pondweed, and concluded that the coot was not interfering with the food supply of the Canvasback.

After Mrs. Priestly's first summer's work, a display of her collections from the Rousay lakes was shown in Yorkton and was well attended by the public. The Yorkton Enterprise featured the event on 2 December 1943:

\section{Rousay Lake Plant Life On Display Interesting Exhibit Shown by Natural History Society}

A most interesting exhibit of plants native to Rousay Lake was on display in a school room in the basement of St. Andrew's United Church on Tuesday afternoon, 31 November, 1943, and evening and attracted a large number of citizens. The display reflected much credit on Mrs. Isabel M. Priestly, the society's president, and Stuart Houston, her valued assistant.

At the request of Ducks Unlimited, members of the Yorkton Natural History Society made an intensive study of the plant and animal life in the Rousay Lake area last summer and as a result, they have a fine set of exhibits to present to the fine sporting organization. But in addition, as a result of their efforts, they are now in a position to render much assistance to the local management committee for the muskrat development project in lakes adjacent to Yorkton, which is also being fostered by Ducks Unlimited.

Register Of Guests As one entered the room where the exhibit was on display, Mike Priestly, the president's small son, asked visitors to sign a register. Stuart Houston then took the visitor in hand to explain the work which he carried on during the past summer and explain pictures of the Ducks Unlimited projects in the Yorkton area.

First Stuart explained how the trap is built and operated to catch birds for banding purposes. Barley is used to attract the birds into the trap and then they are banded and released. Between August 21 and September 21. Stuart banded no less than 556 birds and they included Mallards, Canvasbacks and teals with the last variety constituting about 50 percent of the total number.

Interesting Pictures The pictures of Ducks Unlimited showed many familiar faces and places. There was a fine photograph of Tom Main, the yeneral manager of Ducks Unlimited in Canada, Alderman D.R. Ball, Howard Jackson and others. There was a map on the wall which outlined the York Lake storage projects and the Willowbrook diversion. Stuart Houston stated it was not the intention to allow much more water to flow into York Lake as it flooded the area east of the lake last summer and they wished to prevent this, but a dam was to be placed to divert the water to Leech Lake. 
Stuart also showed the type of bands he used in banding the various birds.

Specimens Of Plant Life Then Mrs. Priestly took over. She showed us 82 specimens of aquatic plants, shorelife plants and upland plants. These are all to go to Ducks Unlimited. The aquatic plants she explained are duck food, and Sago Pondweed and Water Milfoil are the chief plants in Rousay Lake.

The muskrats eat the shoreline plants. They eat the roots and whole plant.

Mrs. Priestly went on to say that the society had duplicates of all these specimens which they hoped would be the basis for a Yorkton museum. They have 125 specimens in all in this collection.

Mrs. Priestly is almost entirely responsible for this exhibit and is deserving of much credit. In addition she is writing the report for Ducks Unlimited.

Mayor Tribute Mayor Peaker, in commenting on the exhibit to The Enterprise, described it as wonderful and said he hoped some day Mrs. Priestly's dream of a museum would come true.

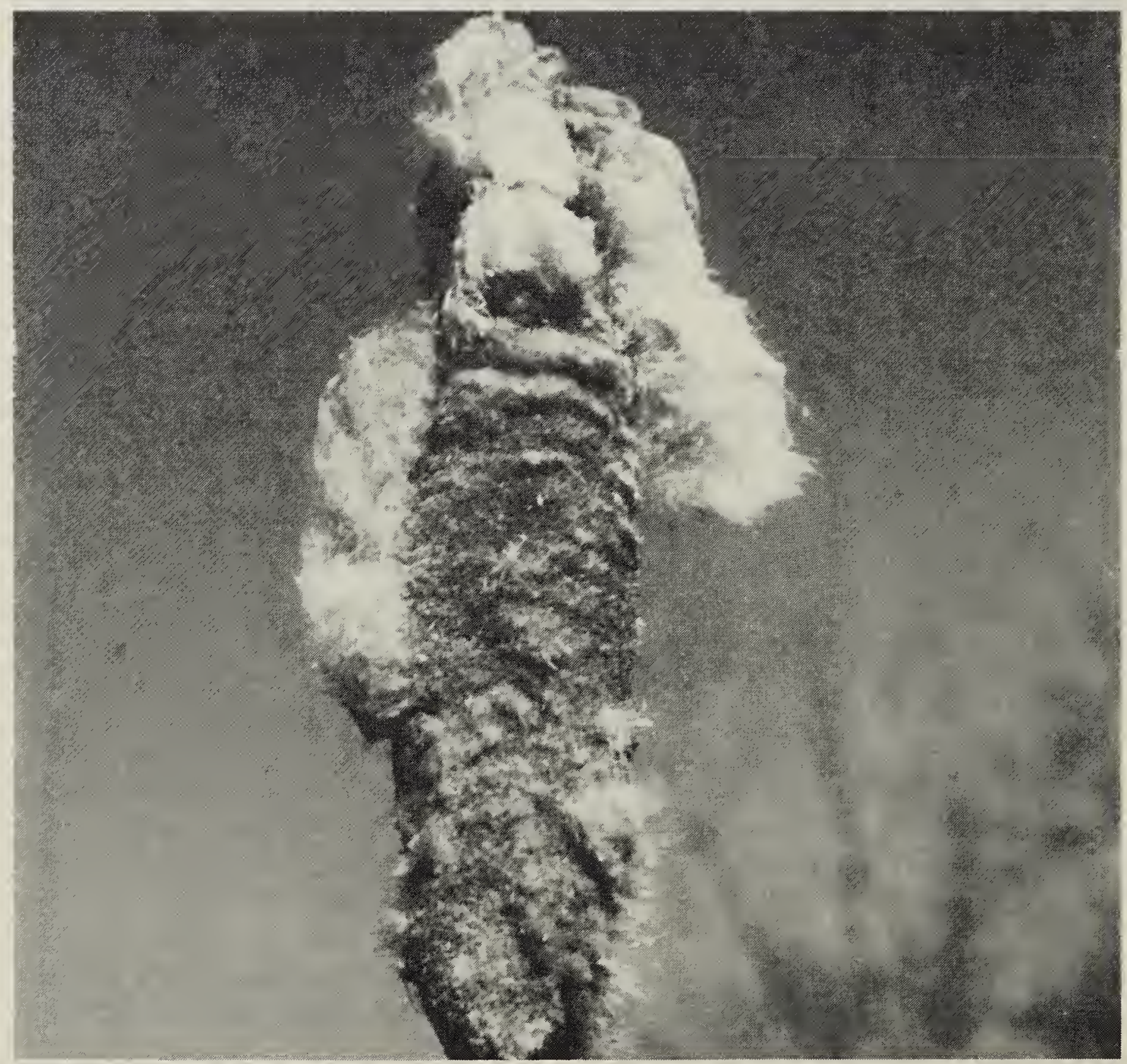

